\title{
연명의료 결정법
}

\author{
김세홍* \\ 가톨릭대학교 성빈센트병원 가정의학과
}

\section{Act on Decisions on Life-Sustaining Treatment}

\section{Se-Hong Kim*}

Department of Family Medicine, St. Vincent's Hospital, The Catholic University of Korea, Suwon, Korea

가정의학(KJFP) 학회지 KJFP 11 권 5호에는 암환자를 대상으로 한 2 편의 원저가 게재되었다. 이승훈 등이 게재한 '연명의료 결정법과 호스피스 의뢰시기'에 대한 연구는 연명의료 결정법 시행이 환자의 자기결정권을 강화하고 호스피스·완화의료로의 의뢰시기를 앞당겼 는지 알아보기 위해 수행된 연구이다. 이 연구에서 연명의료 결정법 시행 이후 통계적으로 유의하지는 않았지만 의뢰시기가 당겨진 경 향성을 보였다. 또한 연명의료 의사 결정과정에 개입되는 다양한 변 수에 대한 통제가 부족한 제한점이 있으나 의뢰 당시의 ECOG, Serum Albumin 등의 여명예측 인자가 통계적으로 유의하게 더 좋은 결과를 확인할 수 있었다. 이것은 품위 있는 죽음을 준비하는 완화 의료의 궁극적인 목적에도 부합하는 결과라고 보여지며 연명의료결 정법의 시행이 호스피스 의뢰시점에 미치는 영향을 알아보기 위한 초기 연구라는 점에서 의미가 있다. 2018년 8월 4일부터 호스피스 완화의료법이 시작됨에 따라 호스피스 완화의료에 대한 관심이 점 점 높아지고 있으나 제도의 효과에 대한 연구는 찾아보기 힘들다. 우리나라는 매년 7만 7천여 명의 암환자가 사망하고 있고, 말기암 환자의 $80 \%-90 \%$ 가 통증으로 고통 받고 있으나, 절반 이상의 암환 자가 적절한 통증 치료를 포함하는 증상 관리를 받지 못하고 있는 실정이다. 또한 전체 사망자의 $63.5 \%$, 암 사망자의 $75.3 \%$, 암을 포함 한 중증질환 사망자의 $70.4 \%$ 가 일반 의료기관에서 치료 도중에 임 종을 맞이하는 것으로 파악되어, 많은 말기환자들이 편안한 임종을 경험하지 못하는 것으로 보고되고 있다. 많은 의료기관의 호스피스 병동에서 가정의학과 전문의가 완화의학 전문가로서 진료 및 연구 의 주축을 담당하고 있는 상황에서 향후 연명의료법의 의학적, 윤
리적, 철학적 영향에 대한 대규모 다기관 연구가 필요할 것으로 생 각된다.

김영식 등은 암환자에서 주관적 불건강 상태와 관련된 요인에 대 한 연구를 게재하였다. 이 연구에서 환자의 질병 유병기간이 길수 록, 현재 스트레스가 심할수록, 우울지수가 높을수록, 원발암이 간 및 췌담관암인 경우 자신의 건강 상태에 대하여 부정적으로 평가하 는 경향이 있다고 저자는 주장하였다. 관련 요인들에 대한 자료와 보정이 충분하지 않은 제한점이 있지만 원발암 부위에 따라 주관적 건강상태에 대한 인식 정도가 다르다는 것은 최초 암 진단자, 암경 험자 및 말기암 환자를 진료하는 가정의학과 의사들에게 시사하는 바가 크다. 완치가 어렵고 통증이 심한 악성 종양일수록 삶의 질을 크게 떨어뜨릴 수 있으며 주치의의 완화의학적 접근이 중요함을 증 명하는 근거자료로 활용할 수 있는 좋은 연구라고 생각된다.

이 외에도 가정의학(KJFP) 학회지 11 권 5 호에는 외래에서 시행하 는 어깨 통증의 평가에 대한 종설이 게재되었다. 이용제 등은 일차 의료 의사가 접하는 매우 흔한 근골격계 문제인 어깨 통증을 진단 하기 위한 문진, 이학적 검사법을 잘 정리하여 기술하였다. 지면의 제한으로 기능적 이학적 검사에 대한 개념을 좀더 자세히 소개하지 못한 아쉬움이 있으나 본 종설의 내용을 숙지하여 적용한다면 어깨 통증으로 내원한 환자를 외래에서 쉽게 진단이 가능할 것으로 생각 된다. 일차진료 현장에서 통증의학 전문가로 활동하고 있는 가정의 학과 의사에게 이용제의 종설은 좋은 참고자료가 될 것이다. 앞으 로도 가정의학 학회지는 전공의 교육 및 일차진료 현장에서 도움이 될 수 있는 임상주제의 종설을 지속적으로 게재하고자 한다.
Received October 18, 2021 Accepted October 18, 2021

Corresponding author Se-Hong Kim

Tel: +82-31-249-8246, Fax: +82-31-249-8006

E-mail: iron1600@catholic.ac.kr

ORCID: https://orcid.org/0000-0001-6465-8993
Copyright () 2021 The Korean Academy of Family Medicine

This is an open-access article distributed under the terms of the Creative Commons Attribution Non-Commercial License (http://creativecommons.org/licenses/by-nc/4.0) which permits unrestricted noncommercial use, distribution, and reproduction in any medium, provided the original work is properly cited. 